\title{
Prenatal follow-up of high-risk pregnancy in the public service
}

\author{
Acompanhamento pré-natal da gestação de alto risco no serviço público \\ Acompañamiento prenatal de la gestación de alto riesgo en el servicio público
}

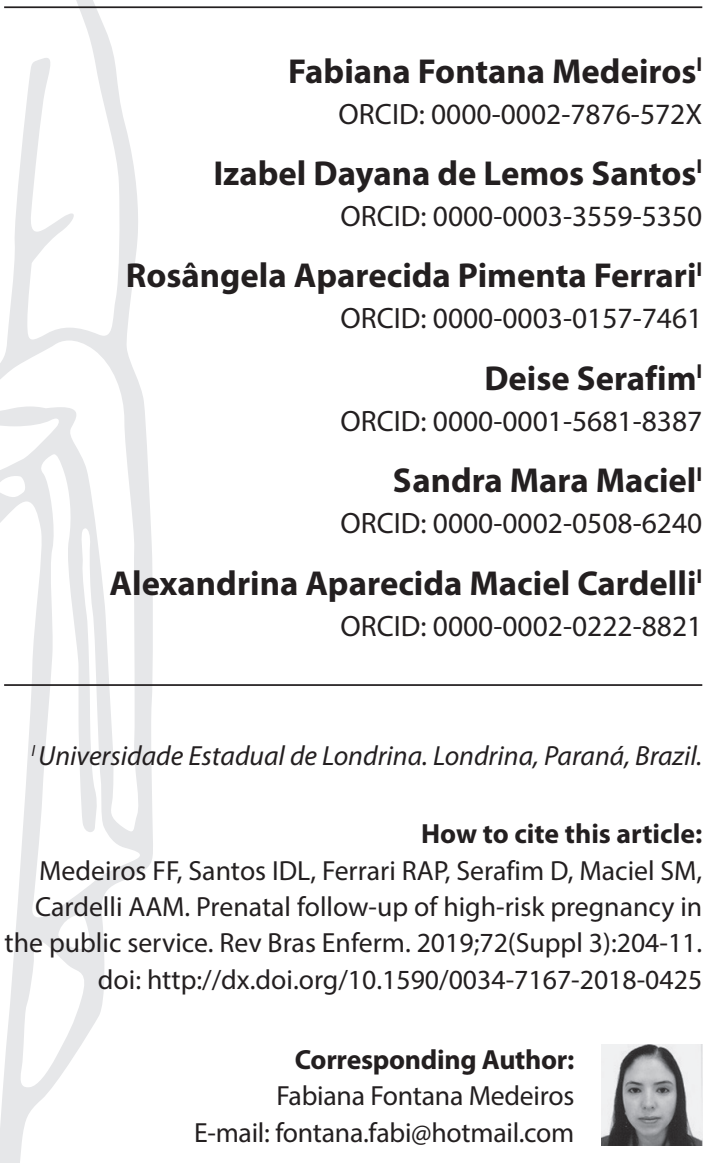

Submission: 06-25-2018
Approval: 11-23-2018

\section{ABSTRACT}

Objective: to analyze the prenatal follow-up of high-risk pregnancy in the public service. Method: an analytical cross-sectional study carried out in a public maternity hospital in the South of Brazil, during the hospitalization of 319 postpartum women using a semistructured tool for transcription of the prenatal card records and interview. The data were analyzed using the Chi-Square test $(p \leq 0.05)$. Results: the adequacy of prenatal care was high (74\%); $22.6 \%$ intermediate; $3.4 \%$ inefficient. Prenatal care had high coverage (100\%), early onset $(81.5 \%)$ and six or more visits $(92.4 \%)$, but $(77.4 \%)$ did not receive information about gestational disease and examinations (69.3\%). There was statistical significance between the quality of prenatal care and the place of prenatal care $(p=0.005)$. Conclusion: the need to implement a specific protocol for high-risk gestation and continuous education to the teams was evidenced.

Descriptors: Women's Health; Prenatal Care; Pregnancy, High-Risk; Health Education; Public Health.

\section{RESUMO}

Objetivo: analisar o acompanhamento pré-natal da gestação de alto risco no serviço público. Método: estudo transversal analítico, realizado em uma maternidade pública no Sul do Brasil, durante internação de 319 puérperas, por meio de instrumento semiestruturado para transcrição dos registros do cartão pré-natal e entrevista. Realizou-se análise dos dados por meio do Teste Qui-Quadrado $(p \leq 0,05)$. Resultados: a adequação do pré-natal foi alta (74\%); $22,6 \%$ intermediária; $3,4 \%$ ineficiente. O pré-natal teve alta cobertura (100\%), início precoce $(81,5 \%)$ e realização de seis ou mais consultas $(92,4 \%)$, porém $(77,4 \%)$ não receberam informação sobre doença gestacional e resultados de exames (69,3\%). Houve significância estatística entre a qualidade do pré-natal e o local da realização do pré-natal $(p=0,005)$. Conclusão: evidenciou-se a necessidade de implementação de protocolo específico à gestação de alto risco e educação continuada às equipes.

Descritores: Saúde da Mulher; Cuidado Pré-Natal; Gravidez de Alto Risco; Educação em Saúde; Saúde Pública.

\section{RESUMEN}

Objetivo: analizar el seguimiento prenatal de la gestación de alto riesgo en el servicio público. Método: el estudio transversal analítico, realizado en una maternidad pública en el Sur de Brasil, durante la internación de 319 puérperas, por medio de un instrumento semiestructurado para la transcripción de los registros de la tarjeta prenatal y la entrevista. Se realizó análisis de los datos por medio del Test Qui-Cuadrado $(p \leq 0,05)$. Resultados: la adecuación del prenatal fue alta (74\%); $22,6 \%$ intermedio; $3,4 \%$ ineficiente. El prenatal tuvo alta cobertura (100\%), inicio precoz $(81,5 \%)$ y realización de seis o más consultas $(92,4 \%)$, pero $(77,4 \%)$ no recibieron información sobre enfermedad gestacional y resultados de exámenes $(69,3 \%)$. Se observó una significativa estadística entre la calidad del prenatal y el lugar de la realización del prenatal $(p=0,005)$. Conclusión: se evidenció la necesidad de implementación de protocolo específico a la gestación de alto riesgo y educación continuada a los equipos.

Descriptores: Salud de la Mujer; Atención Prenatal; Embarazo de Alto Riesgo; Educación en Salud; Salud Pública. 


\section{INTRODUCTION}

Gestation is a determining factor in a woman's life, however it can be a time of suffering when it is not desirable, or when adverse events compromise pregnancy causing health problems or even maternal death ${ }^{(1)}$.

Prenatal follow-up aims to ensure the development of gestation, allowing delivery of a healthy newborn, with no impact on maternal health, including approach to psychosocial aspects and educational activities. Prenatal care can be considered an important indicator of the prognosis at birth, and care in the first quarter is considered an indicator of the quality of maternal care ${ }^{(2)}$.

Brazil has had an increase in the coverage of prenatal care, however it identifies problems in the quality of care, according to procedures recommended by the Ministry of Health ${ }^{(3)}$. The low rates of adequacy of the prenatal process at the various levels can result in undesirable outcomes, such as the birth of premature infants, as well as contribute to maternal and perinatal mortality ${ }^{(4)}$.

In this sense, the quality of prenatal care in the Brazilian Unified Health System (SUS - Sistema Único de Saúde) can be understood through the parameters that make up the Programa de Humanização no Pré-Natal e Nascimento (PHPN - Prenatal and Birth Humanization Program), whose objective is to develop actions for the promotion, prevention and health care of pregnant women and newborns and the Stork Network, with the purpose of structuring and organizing maternal and child health care in the country ${ }^{(2,4-5)}$

Although prenatal quality assessment uses criteria that assess access, consideration should also be given not only to the number of visits or gestational age at the beginning of follow-up, but also to the adequacy of the content of care provided ${ }^{(6)}$.

\section{OBJECTIVE}

To analyze prenatal follow-up of high-risk pregnancy in the public service.

\section{METHOD}

This is a cross-sectional, quantitative-based, nested study to a prospective cohort on adequacy of high-risk prenatal care.

\section{Ethical aspects}

The research was approved by the Research Ethics Committee Involving Human Beings of the Universidade Estadual de Londrina.

\section{Study place}

The study was carried out in a public maternity hospital in the South of Brazil, which is a reference for high-risk delivery. The data collection took place from October 2016 to August 2017.

\section{Sample}

For sample calculation, the number of 1,447 consultations in the year 2015 was considered, with a monthly average of 121 women, a sample error margin of $5 \%$ and a $95 \%$ confidence level, and the sample size of 319 women was defined using the Bareta formula ${ }^{(7)}$.

\section{Inclusion and exclusion criteria}

Women hospitalized in the study maternity who were in the immediate postpartum without cognitive impairment and who had at least one criterion of maternal near miss established by the World Health Organization ${ }^{(8)}$. Women who were hospitalized for abortion or gestational treatment.

\section{Study protocol}

Data collection followed three sequential steps: identification of women according to maternal near miss criteria, consultation and transcription of prenatal card records, hospital records and postpartum interview during hospitalization. It was used to record information semi-structured tool with socioeconomic, demographic and obstetric data. The collection and interviews were performed daily at the institution until the composition of the proposed sample.

As a theoretical-methodological framework, the proposed appropriation of Coutinho et al. was used ${ }^{(9)}$. The authors assessed the care provided to pregnant women at normal or intermediate risk and at high risk, using SUS. Thus, prenatal care was classified as adequate, intermediate or inadequate, according to the records on the pregnant woman's card, considering adequate prenatal care that fulfilled all the following criteria: beginning before 14 gestational weeks; six or more inquiries; minimum number of five or more records of uterine height (UH), gestational age (GA), blood pressure (BP) and maternal weight; four or more fetal heart rate records (FHR); two or more fetal presentation (FP) records and for the basic laboratory tests a blood typing record (ABO-Rh), hemoglobin and hematocrit (Hb/Hct), and two blood glucose registers, Venereal Disease Research Laboratory (VDRL) and urine type 1 (EAS) ${ }^{(9)}$.

The occurrence of one of the following conditions is classified as inadequate: prenatal initiation after 27 weeks of gestation; two or fewer inquiries; two or less notes of UH, GA, BP, maternal weight and FHR, or no FP record, and no laboratory examination annotation. The other associations define the adequacy of the service process as an intermediary ${ }^{(9)}$.

Following the suitability of Coutinho et al. ${ }^{(9)}$, prenatal adequacy variables were adapted for efficient and non-efficient prenatal quality. Efficient prenatal care was considered as an efficient dichotomy, and the dichotomy was not efficient for intermediate and inadequate prenatal care.

\section{Analysis of results, and statistics}

Data were entered and analyzed in the Statistical Package for Social Sciences (SPSS), version 20.0. They were analyzed through the Chi-Square test, to search for possible associations $(p \leq 0.05)$ between the independent variables and the efficient and nonefficient dependent.

\section{RESULTS}

The majority of postpartum women were pregnant (70.5\%), with a partner (86.8\%), living in an urban area (92.5\%), high school education (55.8\%), with unpaid activity (55.2\%) and family income of more than three minimum wages (49.3\%). More than 
half of the women had an interpregnancy interval greater than two years (53\%), and did not plan for pregnancy (56.1\%) (Table 1).

The vast majority of women (87.5\%) were aware of the reason for high risk pregnancy; did not visit prenatal maternity $(91.5 \%)$ and continued with BHU (81.2\%) (Table 2).

Regarding health education, more than half (64.3\%) did not receive guidance on breastfeeding; fetal development (73\%); type of delivery (76.5\%); use of medication (69.6\%); and results of exams (69.3\%). The vast majority of pregnant women did not receive information about gestational disease (77.4\%); sex education (87.1\%); physical activity during pregnancy $(85.6 \%)$ and postpartum follow-up (88.1\%). Most of the women (85.6\%) received information about which hospital to seek in case of emergency (Table 2 ).

Table 1 - Distribution of women according to socioeconomic, demographic and obstetric history, Londrina, Paraná, Brazil, 2017

\begin{tabular}{|c|c|c|}
\hline Variable & $\mathbf{n}$ & $\%$ \\
\hline \multicolumn{3}{|l|}{ Age (years) } \\
\hline 14-19 & 35 & 11.0 \\
\hline $20-35$ & 225 & 70.5 \\
\hline 36 and over & 59 & 18.5 \\
\hline \multicolumn{3}{|l|}{ Race } \\
\hline White & 182 & 57.0 \\
\hline Brown & 95 & 29.8 \\
\hline Black & 42 & 13.2 \\
\hline \multicolumn{3}{|l|}{ Marital status } \\
\hline With a partner & 277 & 86.8 \\
\hline Without a partner & 42 & 13.2 \\
\hline \multicolumn{3}{|l|}{ Residence place } \\
\hline Rural zone & 24 & 7.5 \\
\hline Urban zone & 295 & 92.5 \\
\hline \multicolumn{3}{|l|}{ Origin city } \\
\hline Londrina & 190 & 59.6 \\
\hline Other city & 129 & 40.4 \\
\hline \multicolumn{3}{|l|}{ Schooling } \\
\hline Elementary education & 91 & 28.5 \\
\hline High school & 178 & 55.8 \\
\hline Higher education & 49 & 15.4 \\
\hline \multicolumn{3}{|l|}{ Work type } \\
\hline Paid & 143 & 44.8 \\
\hline Unpaid & 176 & 55.2 \\
\hline \multicolumn{3}{|l|}{ Family income* } \\
\hline Up to 1 minimum wage & 49 & 15.4 \\
\hline From 2 to 3 minimum wages & 115 & 35.3 \\
\hline More than 3 minimum wages & 155 & 49.3 \\
\hline \multicolumn{3}{|l|}{ Parity } \\
\hline Primiparous & 122 & 38.2 \\
\hline Secundiparous & 105 & 32.9 \\
\hline Multiparous & 92 & 28.8 \\
\hline \multicolumn{3}{|l|}{ Interpregnancy interval } \\
\hline Less than 2 years & 39 & 12.2 \\
\hline More than 2 years & 169 & 53.0 \\
\hline \multicolumn{3}{|l|}{ Pregnancy was planned } \\
\hline Yes & 140 & 43.9 \\
\hline No & 179 & 56.1 \\
\hline Total & 319 & 100.0 \\
\hline
\end{tabular}

Note: *Minimum wage base in 2017 - $R \$ 980.00$ (R\$ (real) - Brazilian currency) ( $R \$ 980.00$ is about 245 US dollars).

Risk classification of women was present in $71.5 \%$ of the prenatal card. More than half (57.4\%) contained annotation on prenatal problems, previous pathology (54.9\%); morphological ultrasonography (58.0\%); and 6 or more GA records (81.5\%) in the prenatal card. However, $79.6 \%$ did not present fill of weight chart and edema assessment (88.7\%); and $56.4 \%$ presented only up to two FP records (Figure 1).

Table 2- Distribution of women according to high-risk prenatal care and guidelines, Londrina, Paraná, Brazil, 2017

\begin{tabular}{|c|c|c|}
\hline Variable & $\mathbf{n}$ & $\%$ \\
\hline \multicolumn{3}{|l|}{ Care } \\
\hline \multicolumn{3}{|c|}{$\begin{array}{l}\text { Knowledge on the reason of referral to high-risk } \\
\text { pregnancy }\end{array}$} \\
\hline Yes & 279 & 87.5 \\
\hline No & 12 & 3.8 \\
\hline \multicolumn{3}{|c|}{ Maternity visit } \\
\hline Yes & 22 & 6.9 \\
\hline No & 292 & 91.5 \\
\hline \multicolumn{3}{|c|}{ Follow-up at BHU } \\
\hline Yes & 259 & 81.2 \\
\hline No & 42 & 13.2 \\
\hline \multicolumn{3}{|l|}{ Guidance } \\
\hline \multicolumn{3}{|c|}{ Guidance on maternal breastfeeding } \\
\hline Yes & 114 & 35.7 \\
\hline No & 205 & 64.3 \\
\hline \multicolumn{3}{|c|}{ Guidance on fetal development } \\
\hline Yes & 86 & 27.0 \\
\hline No & 233 & 73.0 \\
\hline \multicolumn{3}{|c|}{ Guidance on delivery type } \\
\hline Yes & 75 & 23.5 \\
\hline No & 244 & 76.5 \\
\hline \multicolumn{3}{|c|}{ Guidance on medication use } \\
\hline Yes & 97 & 30.4 \\
\hline No & 222 & 69.6 \\
\hline \multicolumn{3}{|c|}{ Guidance on gestational illness } \\
\hline Yes & 72 & 22.6 \\
\hline No & 247 & 77.4 \\
\hline \multicolumn{3}{|c|}{ Guidance on sex education } \\
\hline Yes & 41 & 12.9 \\
\hline No & 278 & 87.1 \\
\hline \multicolumn{3}{|c|}{ Guidance on physical activities } \\
\hline Yes & 46 & 14.4 \\
\hline No & 273 & 85.6 \\
\hline \multicolumn{3}{|c|}{ Guidance on exams results } \\
\hline Yes & 98 & 30.7 \\
\hline No & 221 & 69.3 \\
\hline \multicolumn{3}{|c|}{ Guidance on postpartum follow-up } \\
\hline Yes & 38 & 11.9 \\
\hline No & 281 & 88.1 \\
\hline \multicolumn{3}{|c|}{$\begin{array}{l}\text { Guidance on what hospital to go to in case of } \\
\text { emergency }\end{array}$} \\
\hline Yes & 273 & 85.6 \\
\hline No & 25 & 7.8 \\
\hline Total & 319 & 100.0 \\
\hline
\end{tabular}

Regarding the examinations performed in a prenatal card, more than half of the women (56.2\%) did not present the record of the Streptococcus agalactiae test, glucose tolerance test (30.1\%) and hemoglobin electrophoresis (50.8\%) (Figure 1).

The following comorbidities were present in the study sample: hypertension (39.8\%); diabetes mellitus (23.8\%); pre-eclampsia (16.3\%); and obesity (9.4\%). It is worth mentioning that, regarding the lifestyle, $80.6 \%$ of the women were sedentary. 


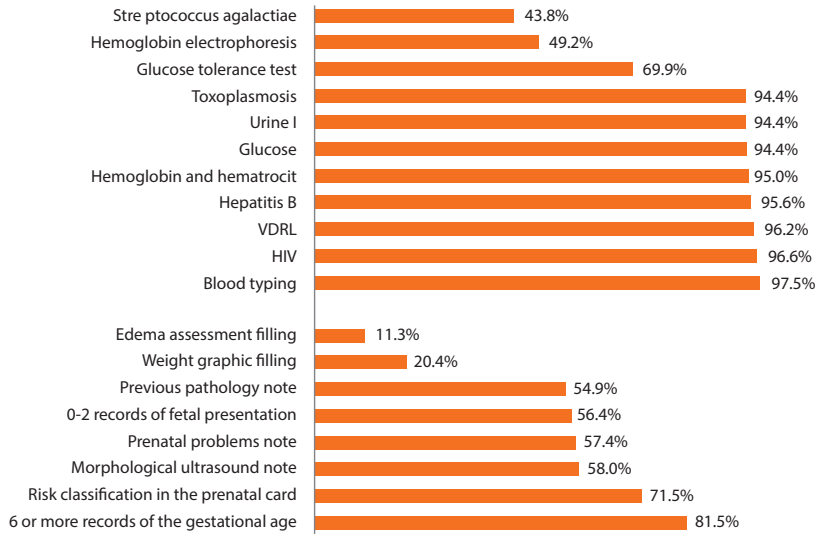

Figure 1- Distribution of examination records and card notes in high-risk prenatal care, Londrina, Paraná, Brazil, 2017

As for prenatal care, $74 \%$ of adequacy was found; $22.6 \%$ were classified as intermediate, and $3.4 \%$ were classified as inadequate.

Among the care recorded in the prenatal care and women's reports, the vast majority (98.7\%) found FHR auscultation, UH
(98.7\%); maternal weight (98.4\%); BP (98.7\%); and (89.0\%) reported no breast examination at prenatal.

The total sample was prenatal, $81.5 \%$ started before the $14^{\text {th }}$ week and $92.4 \%$ had six or more visits (Table 3 ).

Regarding prenatal care, $21.3 \%$ of the pregnant women were treated in Primary Care and referred to the high-risk outpatient clinic at the end of gestation for delivery. However, $78.7 \%$ of the visits occurred concurrently in Primary and Secondary Care, the latter being in an outpatient clinic for high-risk gestation, presenting $82.6 \%$ of efficiency. There was $32.5 \%$ of inefficiency in Primary Care. There was a statistically significant association between the place of performance and prenatal quality $(p=0.005)$. The risk of ineffective prenatal care for women in this study in Primary Care was 64\% higher than in Primary Care associated with Secondary Care. There was also a statistical difference between the city in which prenatal care was performed and prenatal quality $(p=0.003)$. Women who performed prenatal care in other municipalities had a 54\% higher likelihood of follow-up efficiency than those who performed in the city of Londrina (Table 3).

Table 3 - Distribution of the prenatal quality according to some characteristics of this follow-up, Londrina, Paraná, Brazil, 2017

\begin{tabular}{|c|c|c|c|c|c|c|c|c|}
\hline Variable & \multicolumn{2}{|c|}{$\begin{array}{c}\text { Efficient prenatal quality } \\
\mathbf{n}\end{array}$} & \multicolumn{2}{|c|}{$\underset{n}{\text { Non-efficient prenatal quality }}$} & \multicolumn{2}{|c|}{ Total } & OR & $\begin{array}{c}p \\
\text { value* }\end{array}$ \\
\hline \multicolumn{9}{|l|}{ Place of prenatal performance } \\
\hline Primary Care & 41 & 17.4 & 27 & 32.5 & 68 & 21.3 & 0.436 & 0.005 \\
\hline Secondary and Primary Care & 195 & 82.6 & 56 & 67.5 & 251 & 78.7 & & \\
\hline \multicolumn{9}{|l|}{ City of prenatal performance } \\
\hline Londrina & & 38.6 & 48 & 57.8 & 139 & 43.6 & 0.458 & 0.003 \\
\hline Other municipalities of Paraná State & & 61.4 & 35 & 42.2 & 180 & 56.4 & & \\
\hline \multicolumn{9}{|l|}{ Waiting time for high-risk follow-up } \\
\hline Up to 1 week & 41 & 21.1 & 17 & 29.8 & 58 & 23.1 & - & 0.210 \\
\hline Above 1 week & 153 & 78.9 & 40 & 70.2 & 193 & 76.9 & & \\
\hline \multicolumn{9}{|l|}{ Prenatal onset } \\
\hline$<14$ th week & 216 & 92.3 & 39 & 49.4 & 255 & 81.5 & & \\
\hline 14th -27 th week & 18 & 7.7 & 36 & 45.6 & 54 & 17.3 & - & 0.0001 \\
\hline$>27$ th week & - & - & 4 & 5.1 & 4 & 1.3 & & \\
\hline \multicolumn{9}{|l|}{ Number of consultations } \\
\hline 6 or more & 234 & 99.2 & 57 & 72.2 & 291 & 92.4 & & \\
\hline $0-2$ & - & - & 1 & 1.3 & 1 & 0.3 & & 0.0001 \\
\hline $3-5$ & 2 & 0.8 & 21 & 26.6 & 23 & 7.3 & & \\
\hline \multicolumn{9}{|l|}{ Number of ultrasounds in the 1 st quarter } \\
\hline 1 & 113 & 47.9 & 37 & 44.6 & 150 & 47.0 & & \\
\hline 2 or more & 100 & 42.4 & 22 & 26.5 & 122 & 38.2 & - & 0.0001 \\
\hline No records & 23 & 9.7 & 24 & 28.9 & 47 & 14.7 & & \\
\hline \multicolumn{9}{|l|}{ Gestational age at the first ultrasound } \\
\hline Up to 14 th week & 193 & 81.8 & 47 & 56.6 & 240 & 75.2 & - & \\
\hline $15^{\mathrm{a}}$ to 27 th week & 26 & 11.0 & 22 & 26.5 & 48 & 15.0 & & 0.0001 \\
\hline Above the 27 th week & - & - & 3 & 3.6 & 3 & 0.9 & & \\
\hline \multicolumn{9}{|l|}{ Oncotic cytology collection } \\
\hline Collected in less than 1 year & 61 & 25.8 & 31 & 37.8 & 92 & 28.9 & & \\
\hline Collected at prenatal & 91 & 38.6 & 39 & 47.6 & 130 & 40.9 & - & 0.0001 \\
\hline Not performed & 84 & 35.6 & 11 & 14.6 & 95 & 30.2 & & \\
\hline \multicolumn{9}{|l|}{ Participation in pregnant women group } \\
\hline Yes & 60 & 25.4 & 15 & 18.1 & 75 & 23.5 & - & \\
\hline No & 176 & 74.6 & 68 & 81.9 & 244 & 76.5 & & 0.174 \\
\hline \multicolumn{9}{|c|}{ Guidance on what hospital to go to in case of emergency } \\
\hline Yes & 185 & 78.4 & 56 & 67.5 & 241 & 75.5 & 1.749 & 0.046 \\
\hline No & 51 & 21.6 & 27 & 32.5 & 78 & 24.5 & & \\
\hline
\end{tabular}




\begin{tabular}{|c|c|c|c|c|c|c|c|c|}
\hline \multirow{2}{*}{ Variable } & \multicolumn{2}{|c|}{ Efficient prenatal quality } & \multicolumn{2}{|c|}{ Non-efficient prenatal quality } & \multicolumn{2}{|c|}{ Total } & \multirow{2}{*}{ OR } & \multirow{2}{*}{$\underset{\text { value* }}{p}$} \\
\hline & $\mathbf{n}$ & $\%$ & & $\%$ & $\mathbf{n}$ & $\%$ & & \\
\hline \multicolumn{9}{|c|}{ Interval between the first and last consultation and delivery } \\
\hline 0-15 days & 213 & 90.3 & 67 & 80.7 & 280 & 87.8 & 2.212 & 0.031 \\
\hline 16 days and more & 23 & 9.7 & 16 & 19.3 & 39 & 12.2 & & \\
\hline Total & 236 & 100.0 & 83 & 100.0 & 319 & 100.0 & & \\
\hline
\end{tabular}

Note: *Chi-Square test $(p<0.05)$

There was no statistical significance between waiting time for high-risk follow-up with the outcome of prenatal quality $(p=0.210)$. However, $18.1 \%$ of the women waited up to 1 week to start high-risk follow-up. There was statistical significance between prenatal onset and prenatal quality $(p=0.0001)$. The vast majority (92.3\%) ho started prenatal care before 14 weeks of GA had an efficient follow-up. The number of visits was also associated with prenatal quality ( $p=0.0001) ; 99.2 \%$ of the women who had 6 or more consultations had an efficient prenatal care. Already inserted in prenatal care, oncotic cytology collection showed a statistically significant difference $(p=0.0001)$ (Table 3 ).

There was a statistically significant association between the number of ultrasounds in the first quarter ( $p=0.0001)$; $G A$ of the first ultrasound $(p=0.0001)$ and prenatal quality. The higher the number of ultrasound performed in the first quarter, the better the prenatal efficiency. On the other hand, the higher the GA in the first ultrasound, the greater the decline in prenatal efficiency (Table 3 ).

There was a statistically significant difference between the interval of the last prenatal visit for delivery $(p=0.031)$; guidance on which hospital to seek during emergencies $(p=0.046)$; and the quality of prenatal care. Women with a last consultation interval and labor between 16-30 days had a $21 \%$ risk of prenatal inefficiency, and the non-guidance of demand from the referral hospital resulted in $25 \%$ of inefficiency in prenatal quality (Table 3 ).

\section{DISCUSSION}

Studies have shown the increase in prenatal care coverage across the country in the last ten years, but the quality of prenatal care has been found to be inadequate. Among the factors that contribute to the low quality of prenatal care, the non-performance of routine laboratory exams, recommended basic procedures, prescriptions and guidelines during consultations were highlighted ${ }^{(3,10-11)}$.

The present study pointed out that the quality of prenatal care was influenced by the health care follow-up, the city in which it was performed, its onset, number of visits, number of ultrasounds in the first quarter, GA on the first ultrasound, cytology collection oncotic, guidance on hospital referral for emergency and interval between last prenatal consultation and delivery.

Social and demographic characterization of the women in this study, in relation to age, marital status and schooling was similar to that found in other studies, with a predominance of pregnant women of favorable reproductive age, with partner and high school ${ }^{(11-13)}$. On the other hand, family income was above that found in other surveys ${ }^{(12-13)}$.

In this study, although pregnancy was not planned, there was an early prenatal start. It is worth noting the occurrence of personal failure in reproductive planning, despite the inherent vulnerability to risk gestation and its possible aggravations.
It is considered high-risk pregnancy, situations in which women's health is affected by complications related to preexisting diseases or intercurrences of pregnancy, labor or postpartum, generated by organic or socio-economic and demographic unfavorable factors. The risk pregnant woman should be referred to the referral service, having the care guaranteed in the establishment of origin from the time of referral until the end of gestation, with the transit facilitated between the health services, ensuring adequate care in a timely manner. Risk assessment should occur individually during the anamnesis, with reassessment of gestational risk in all prenatal consultations ${ }^{(14)}$.

Women's knowledge about high-risk pregnancies was satisfactory, with follow-up being followed by the Basic Health Unit. Similar to another study ${ }^{(15)}$, a large proportion of women who did not visit the maternity hospital during prenatal follow-up.

It is believed that the visit to the maternity hospital in prenatal care may not be occurring because the professional does not identify the importance of the visit, a fact that may be influenced by the team, institution and team organization. Although the linkage of pregnant women to maternity care for labor care has been regulated since 2007 (Law 11.634 of December 27, 2007) and is a recommendation of the Stork Network, in the integration of prenatal care services and delivery, aiming at the reception of parturients and the guarantee of bed for hospitalization, improvements are necessary, aiming to avoid the pilgrimage of pregnant women, still frequent in many places of the country ${ }^{(11)}$.

A Brazilian study on quality indicators in prenatal care has shown that among the guidelines received, exclusive breastfeeding is the most offered. The study emphasized that the guidelines are associated with maternal age; the higher the age group, the greater the proportion of guidance received. In relation to income, lower income women received less guidance during prenatal care. Another evidence was the relation regarding the size of the municipality, because the higher the prevalence of guidelines provided to pregnant women during prenatal care ${ }^{(16)}$. Different from the present study, Londrina presented inefficient prenatal care.

The main prenatal care is directed to the physical examination,

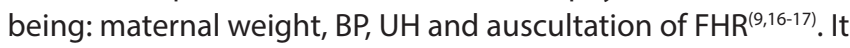
was observed that among the care performed in the present study, information on prenatal care was insufficient, being directed to emergency situations and performing a physical examination. Prenatal care follow-up should meet the individual needs of the woman, with active listening, identification of doubts and fears.

The provision of guidelines does not imply costs for the SUS, being solely dependent on the attitude of professionals. Faced with this, it is questionable whether training may be scarce or if the lack of time during the journey, characterized by the achievement of goals established by the management, may be compromising the quality of the service ${ }^{(16)}$. 
Pregnant women groups can be a valuable resource because it is a strong channel of guidance. However, for the study sample, this health action was not implemented during prenatal care. It is believed that the nurse, when conducting group activities, can reach a significant number of women in a single moment, being this educational strategy beneficial to the health of the pregnant woman, contributing to the effectiveness of prenatal care.

Similar to another study, the coverage of pre-natal examinations performed during prenatal care was satisfactory ${ }^{(3)}$. However, it was verified that the tests performed less frequently were for the detection of Streptococcus agalactiae, glucose tolerance test and hemoglobin electrophoresis.

The prenatal follow-up of the study sample, performed in Secondary Care, concomitant to Primary Care, showed an efficient quality. It can be inferred that the level of quality found was determined by factors, such as being structured in an outpatient clinic; access to the necessary inputs for this follow-up; availability of specific exams; and professionals prepared to serve this population group.

The city in which prenatal care was performed was also determinant in the quality of this care. Women who performed prenatal care in Primary Care in other municipalities of Paraná State presented higher quality in follow-up. This fact may be being determined by the workload of the professionals who provide prenatal care in the city of Londrina, as well as by the greater demand of the service when compared to other municipalities. In any case, this evidence pointed out in the present study needs to be deepened for its real understanding.

This study confirmed the adequacy of prenatal coverage similar to other studies ${ }^{(3,11,18)}$, resulting in an efficient prenatal care. According to the World Health Organization, the appropriate number of prenatal consultations should be equal to or greater than six. Special attention should be paid to pregnant women at greater risk, where consultations should be monthly up to the $28^{\text {th }}$ week, biweekly between 28-36 weeks and weekly in the term. It is worth mentioning that there is no discharge from prenatal care, and the consultation must be continued until the time of delivery ${ }^{(2)}$.

Pregnancy risk assessment and stratification should occur at the first and subsequent prenatal visits, allowing adequate guidance and referrals at each time of pregnancy ${ }^{(19)}$.

It is noteworthy that there was a significant percentage of prenatal inefficiency among women who did not have information in the pregnant women's book about the ultrasound in the first quarter. The lack of records in the prenatal card is something that may interfere with the quality of this care. This document is an important means of communication between the teams for better.

Improving the quality of prenatal care involves adequate registration on the pregnant woman's card to diagnose gestational risk, continuous technical training of health professionals, as well as compliance with pre-established technical standards and commitment to the population's needs ${ }^{(20)}$.

It was also observed that the performance of the first ultrasound until the $14^{\text {th }}$ gestational week pointed to the efficient prenatal, showing once again that the early onset of prenatal favors the early performance of the ultrasound and, consequently, possible diagnoses in a timely manner.

The investigation of basic prenatal practices is suggested by some authors who affirm that although they are part of the routine, they are not always performed ${ }^{(21)}$.
Oncology cytology collection is an example of this situation and was verified in the present study, also pointing to the efficient prenatal quality. Pregnancy can be a time for preventive exams. Studies show that gynecological examination is the least performed exam in prenatal care ${ }^{(16)}$.

The Pap smear is of extreme importance in reducing female morbidity and mortality from cervical cancer. It is a low-cost, easy-to-apply exam with no burden and detriment to the patient. Pregnancy represents a good opportunity for the prevention of this type of cancer, considering that the pregnant women attend more frequently to the Health Unit.

It was observed in the present study that the last prenatal visit occurred within a period of up to 15 days before delivery, being a determinant of prenatal efficiency. It was also noted that the longer the interval between the last prenatal visit and delivery, the prenatal care was inefficient. The end of gestation is the period in which there may be a greater probability of obstetric complications, and the pregnant woman must be followed frequently, ending her follow-up when she is admitted to the maternity ward for delivery ${ }^{(22)}$.

In high-risk prenatal care, consultations frequency is determined by the team responsible, according to the needs and priorities of each pregnant woman. The health team, which carries out the follow-up of high-risk pregnancies, should consider: clinical assessment, obstetric assessment, repercussions between the clinical conditions of the pregnant woman and the pregnancy, determination of the way of delivery, emotional and psychosocial aspects ${ }^{(23)}$.

The guidance on which hospital to look for in an emergency resulted in efficient prenatal care. Studies show that the proportion of maternity-oriented pregnant women with reference to admission to delivery is low ${ }^{(3,11)}$. One of the flaws found in prenatal care is due to the precariousness in the articulation between prenatal and delivery services ${ }^{(11)}$.

\section{Study limitations}

As limit of this study, it is pointed out the transversal character that assessed the object by a certain time. However, the information is representative and can serve as a basis for further studies.

\section{Contributions to Nursing and Health}

The present study pointed out an important diagnosis for the health professionals, and can be used as a subsidy for the improvement of prenatal care.

\section{CONCLUSION}

The quality of prenatal care among the women in this study was influenced by the site, that is, city of prenatal performance, prenatal start, number of visits performed, number of ultrasound performed in the first quarter, GA at the first ultrasound, oncology cytology collection, guidance on what hospital to seek emergency and interval between the last prenatal and delivery visit.

In view of these findings, prenatal adequacy was satisfactory, but gaps were identified in the organization of high-risk prenatal care, as well as in the actual care, aiming for qualification 
in follow-up. The lack of guidance to pregnant women was an important fact, which highlights the need for teams performing high-risk prenatal care to review their educational practices.

In order to reach prenatal care quality, health managers should provide appreciation to prenatal care professionals, as well as continuing education for the improvement of interdisciplinary teams and inclusion of the midwife in the Primary and Secondary Care of the health service. It is suggested the implementation of specific protocols for high-risk pregnancy in order to achieve effectiveness in prenatal care.

\section{REFERENCES}

1. Fekadu M, Regassa N. Skilled delivery care service utilization in Ethiopia: analysis of rural-urban differentials based on national demographic and health survey (DHS) data. Afr Health Sci. 2014;14(4):974-84. doi: 10.4314/ahs.v14i4.29

2. Ministério da Saúde (BR). Secretaria de Atenção à Saúde. Departamento de Atenção Básica. Atenção ao pré-natal de baixo risco [Internet]. Brasília: Ministério da Saúde; 2012 [cited 2018 Apr 12] (Cadernos de Atenção Básica n 32). Available from: http://bvsms.saude.gov.br/bvs/ publicacoes/cadernos_atencao_basica_32_prenatal.pdf

3. Domingues RMSM, Viellas EF, Dias MAB, Torres JA, Theme-Filha MM, Gama SGNL, et al. Adequação da assistência pré-natal segundo as características maternas no Brasil. Rev Panam Salud Pública [Internet]. 2015 [cited 2018 Apr 12];37(3):140-7. Available from: https://www. scielosp.org/pdf/rpsp/2015.v37n3/140-147/pt

4. Martinelli KG, Santos-Neto ET, Gama SGN, Oliveira AE. Adequação do processo da assistência pré-natal segundo os critérios do Programa de Humanização do Pré-natal e Nascimento e Rede Cegonha. Rev Bras Ginecol Obstet. 2014;36(2):56-64. doi: 10.1590/\$0100-72032014000200003

5. Ministério da Saúde (BR). Portaria n 569, de $1^{\circ}$ de junho de 2000. Institui o Programa de Humanização no Pré-natal e Nascimento, no âmbito do Sistema Único de Saúde (SUS) [Internet]. Brasília: Ministério da Saúde; 2000 [cited 2018 Apr 12]. Available from: http://bvsms. saude.gov.br/bvs/saudelegis/gm/2000/prt0569_01_06_2000_rep.html

6. Polgliane RBS, Leal MC, Amorim MHC, Zandonade E, Santos-Neto ET. Adequação do processo de assistência pré-natal segundo critérios do Programa de Humanização do Pré-natal e Nascimento e da Organização Mundial de Saúde. Ciênc Saúde Colet. 2014;19(7): 1999-2010. doi: $10.1590 / 1413-81232014197.08622013$

7. Bareta PA. Fórmula para o cálculo do tamanho mínimo da amostra. Estatística aplicada às ciências sociais. 8 a ed. Florianópolis: UFSC; 2012

8. Organização Mundial da Saúde (OMS). Avaliação da qualidade do cuidado nas complicações graves da gestação: a abordagem do near miss da OMS para a saúde materna [Internet]. Geneva: OMS; 2011 [cited 2018 Apr 12]. Available from: https://www.paho.org/clap/index. php?option=com_docman\&view=download\&category_slug=guias-clinicas-3\&alias=405-avaliacao-da-qualidade-do-cuidado-nascomplicacoes-graves-da-gestacao-a-abordagem-do-near-miss\&ltemid=219\&lang=es

9. Coutinho T, Monteiro MFG, Sayd JD, Teixeira MTB, Coutinho CM, Coutinho LM. Monitoramento do processo de assistência pré-natal entre as usuárias do Sistema Único de Saúde em município do Sudeste brasileiro. Rev Bras Ginecol Obstet. 2010;32(11):563-9. doi: 10.1590/ S0100-72032010001100008

10. Nunes JT, Gomes KRO, Rodrigues MTP, Mascarenhas MDM. Qualidade da assistência pré-natal no Brasil: revisão de artigos publicados de 2005 a 2015. Cad Saúde Colet. 2016;24(2):252-61. doi: 10.1590/1414-462X201600020171

11. Viellas EF, Domingues RMSM, Dias MAB, Gama SGN, Theme-Filha MM, Costa JV, et al. Prenatal care in Brazil. Cad Saúde Pública. 2014;30(Suppl. 1):S1-15. doi: 10.1590/0102-311X00126013

12. Santos JGC, Silva JMC, Passos AMPR, Monteiro BKSM, Maia MM, Silva, RA, et al. Peso materno em gestantes de baixo risco na atenção prénatal. Int J Nutr. 2017;10(2):5-15

13. Morais AODS, Simões VMF, Rodrigues LS, Batista RFL, Lamy ZC, Carvalho CA, et al. Sintomas depressivos e de ansiedade maternos e prejuízos na relação mãe/filho em uma coorte pré-natal: uma abordagem com modelagem de equações estruturais. Cad Saúde Pública. 2017;33(6):e00032016. doi: 10.1590/0102-311x00032016

14. Ministério da Saúde (BR). Portaria no 1.020, de 29 de maio de 2013. Institui as diretrizes para a organização da Atenção à Saúde na Gestação de Alto Risco e define os critérios para a implantação e habilitação dos serviços de referência à Atenção à Saúde na Gestação de Alto Risco, incluída a Casa de Gestante, Bebê e Puérpera (CGBP), em conformidade com a Rede Cegonha [Internet]. Brasília: Ministério da Saúde; 2013 [cited 2018 Apr 12]. Available from: http://bvsms.saude.gov.br/bvs/saudelegis/gm/2013/prt1020_29_05_2013.html

15. Pedraza DF. Assistência ao pré-natal, parto e pós-parto no município de Campina Grande, Paraíba. Cad Saúde Colet. 2016;24(4):460-7. doi: 10.1590/1414-462×201600040092

16. Tomasi E, Fernandes PAA, Fischer T, Siqueira FCV, Silveira DS, Thumé E, et al. Qualidade da atenção pré-natal na rede básica de saúde do Brasil: indicadores e desigualdades sociais. Cad Saúde Pública. 2017;33(3):e00195815. doi: 10.1590/0102-311x00195815

17. Valente MMQP, Freitas NQ, Áfio ACE, Sousa CSP, Evangelista DR, Moura ERF. Prenatal care: a look at the quality. Rev Rene [Internet]. 2013;14(2):280-9 [cited 2018 Apr 12]. Available from: http://periodicos.ufc.br/rene/article/view/3376

18. Alves VM, Nicácio TS, Oliveira RMS, Pereira-Netto M. Qualidade da assistência pré-natal numa Unidade Básica de Saúde do município de Juiz de Fora - MG [Internet]. J Manag Prim Heal Care. 2016 [cited 2018 Apr 12];7(1):153-3. Available from: http://www.jmphc.com.br/saudepublica/index.php/jmphc/article/view/495.pdf 
19. Secretaria de Estado da Saúde do Paraná (SESA). Superintendência de Atenção à Saúde. Caderno de atenção no pré-natal risco habitual [Internet]. Curitiba: SESA; 2013 [cited 2018 Apr 12]. Available from: http://www.saude.pr.gov.br/arquivos/File/pdf6.pdf

20. Paris GF, Pelloso SM, Martins PM. Qualidade da assistência pré-natal nos serviços públicos e privados. Rev Bras Ginecol Obstet. 2013;35(10):447-52. doi: 10.1590/S0100-72032013001000004

21. Santana JEO, Santos M, Machado ILD. A importância da realização do papanicolaou em gestantes: uma revisão de literatura. Cad Grad Ciênc Biol Saúde [Internet]. 2013 [cited 2018 Apr 12];17(1):39-48. Available from: https://periodicos.set.edu.br/index.php/cadernobiologicas/ article/view/581

22. Ministério da Saúde (BR). Secretaria de Atenção à Saúde. Departamento de Ações Programáticas Estratégicas. Manual de acolhimento e classificação de risco em obstetrícia [Internet]. Brasília: Ministério da Saúde; 2014 [cited 2018 Apr 12]. Available from: http://portalarquivos2. saude.gov.br/images/pdf/2014/maio/29/Manual-de-ACR-em-Obstetricia-versao-26-de-maio--4-.pdf

23. Ministério da Saúde (BR). Secretaria de Atenção à Saúde. Departamento de Atenção Básica. Diretrizes do NASF: Núcleo de Apoio a Saúde da Família [Internet]. Brasília: Ministério da Saúde; 2010 [cited 2018 Apr 12]. Available from: http://bvsms.saude.gov.br/bvs/publicacoes/ diretrizes_do_nasf_nucleo.pdf 